\title{
Masculinidades Violentas e Indignação Moral: Percepções sobre a utilização da Monitoração Eletrônica conjugada com Grupos Reflexivos de Gênero para agressores em Belo Horizonte/MG ${ }^{1}$
}

\author{
Violent Masculinities and Moral Indignation: Perceptions about \\ the use of Electronic Monitoring in conjunction with Reflective \\ Gender Groups for aggressors in Belo Horizonte/MG
}

Welliton Caixeta Maciel ${ }^{2}$

\section{RESUMO}

Neste artigo, enfoco a questão da utilização de tornozeleiras eletrônicas em homens autores de violência doméstica contra mulheres em Belo Horizonte/MG e o posterior encaminhamento destes sujeitos a grupos reflexivos de gênero. Por meio do método etnográfico, no que pude acompanhar, a implementação da referida política naquela localidade, analiso a percepção dos diversos atores institucionais envolvidos e, principalmente, dos próprios monitorados, sobre o cotidiano de cumprimento de tais medidas (protetivas e alternativas) e o processo de construção de uma responsabilização atribuída a esses homens por meio da dinâmica das intervenções psicossociais. Todavia, a pesquisa mostrou que a questão das masculinidades violentas é demandante de mudanças culturais mais significativas, sendo que o arcabouço judiciário e judicializante não tem sido capaz de comportar satisfatoriamente as demandas ético-morais legítimas das partes, dificultando que sejam alcançadas soluções justas ou equânimes.

\section{PALAVRAS-CHAVE:}

Violência doméstica; masculinidades violentas; vigilância eletrônica; grupos reflexivos de gênero; etnografia de política pública.

\footnotetext{
${ }^{1}$ Versão resumida/adaptada do Capítulo 4 de minha dissertação de mestrado intitulada “'Os 'Maria da Penha': uma etnografia de mecanismos de vigilância e subversão de masculinidades violentas em Belo Horizonte”, defendida, em março de 2014, junto ao Programa de Pós-Graduação em Antropologia Social da Universidade de Brasília (PPGAS/UnB).

${ }^{2}$ Doutorando em Direito, Estado e Constituição pela Universidade de Brasília (UnB), tendo realizado pesquisa de campo durante estágio junto ao Centre de recherches Sociologiques sur le Droit et les Institutions Pénales (CESDIP/CNRS/Ministère de la Justice/Université de Versailles-Saint-Quentin - UVSQ/Université de CergyPontoise - UCP/Université Paris-Saclay), bem como à École des hautes études en sciences sociales (EHESS), de Paris/França. Mestre em Antropologia Social, graduado em Ciências Sociais - Sociologia e Antropologia, pela UnB, e em Direito, pela UDF. Professor substituto/voluntário de Direito Penal (2015) e professor voluntário de Antropologia do Direito (Atualização e Prática em Direito 1, 2, 3 e 5) (2016 - atual), na Faculdade de Direito da Universidade de Brasília (UnB). E-mail: wellitonmaciel@gmail.com.
} 


\begin{abstract}
In this article, I focus on the issue of the use of electronic anklets in men who commit domestic violence against women in Belo Horizonte / MG and the subsequent referral of these subjects to reflective gender groups. Through the ethnographic method, as far as I could follow, the implementation of that policy in that city, I analyze the perception of the various institutional actors involved and, mainly, of the monitored themselves, about the day-to-day compliance with such measures (protective and alternative) and the process of building accountability attributed to these men through the dynamics of psychosocial interventions. However, my research has shown that the issue of violent masculinities demands more significant cultural changes, and the judiciary and judicial framework has not been able to satisfactorily meet the legitimate ethical-moral demands of the parties, making it difficult to achieve just or equitable solutions.
\end{abstract}

\title{
KEYWORDS:
}

Domestic violence; violent masculinities; electronic surveillance; reflective gender groups; public policy ethnography.

\section{INTRODUÇÃO}

Em Minas Gerais, mais especificamente na Região Metropolitana de Belo Horizonte/MG, desde 2012, tem-se utilizado a vigilância eletrônica de pessoas por meio de tornozeleiras eletrônicas como forma de garantir o cumprimento de medidas protetivas aplicadas por juízes conjugadamente à obrigatoriedade de frequentar grupos reflexivos destinados prioritariamente a homens autores de violência contra mulheres às quais é conferido facultativamente um dispositivo portátil que controla, vigia e comunica a uma Central (ou Unidade Gestora de Monitoração Eletrônica da Secretaria de Estado de Defesa Social de Minas Gerais - UGME/SEDS), em caso de aproximação e violação da determinação judicial por parte de supostos agressores que, após a judicialização dos casos nos quais figuram como réus, deixam de ser socialmente classificados somente como 'batedores de mulheres' passando à categoria de 'Maria da Penha', com sua liberdade vigiada.

Diante desta situação, no escopo de minha pesquisa de mestrado em Antropologia Social, orientado pelo método etnográfico de pesquisa, acompanhei in loco, entre novembro de 
2012 e novembro de 2013, a implementação da referida política, com a utilização de tornozeleiras eletrônicas em homens autores de violência contra mulheres e o acompanhamento do cumprimento desta e de outras medidas cautelares naquela localidade.

Com isto, busquei analisar a percepção dos diversos atores institucionais envolvidos e, principalmente, dos próprios monitorados, sobre o cotidiano do cumprimento de tais medidas (protetivas e alternativas) e o processo de construção de uma 'responsabilização' atribuída a esses homens por meio da dinâmica das intervenções psicossociais, como forma de enfrentamento à violência intrafamiliar e doméstica em Belo Horizonte.

Interessou-me, portanto, compreender: 1) como a monitoração eletrônica e outras medidas são vividas pelos 'Maria da Penha', se e de que maneira repercutem em suas visões de mundo, sobre direitos, relações sociais de gênero etc.; 2) se a apreensão e o processamento de casos pelo sistema de justiça criminal ou, simplesmente, se a judicialização e o recurso a mecanismos de vigilância e controle são capazes de interferir nas masculinidades e nos comportamentos violentos desses indivíduos, muitas vezes após terem experienciado (ou não) o encarceramento; 3 ) se todas essas alternativas podem trazer certo apaziguamento às relações intrafamiliares e/ou garantir o reconhecimento a outros tipos de demandas.

Neste artigo, porém, atenho-me à análise do material de campo junto aos grupos reflexivos de gênero e as entrevistas com interlocutores centrais, no que apresento etnograficamente o processo de construção da política pública de intervenção com homens autores de violência intrafamiliar e doméstica por meio de grupos reflexivos de gênero em Belo Horizonte.

A partir da visão de atores institucionais e dos monitorados/participantes, busco compreender se a aplicação da medida cautelar de monitoração eletrônica conjugada com a obrigatoriedade em frequentar tais grupos tem proporcionado algum tipo de mudança, transformação ou subversão em termos do trabalho com essas 'masculinidades violentas'; bem como a perspectiva dos agentes envolvidos (sobretudo, os próprios monitorados/participantes) com relação ao processo como concebem, aprendem, ensinam, reproduzem, imaginam, mentalizam, subjetivam, objetivam, interpretam, significam, representam e simbolizam essas violências e a noção de direitos a partir de suas histórias e trajetórias individuais. Passemos à etnografia e seus desdobramentos analíticos. 


\section{MASCULINIDADES VIOLENTAS EM PERFORMANCE}

Era final da tarde do dia 12 de junho de 2013, quando cheguei ao Instituto Mineiro de Saúde Mental e Social - Instituto ALBAM, localizado na rua Ceará, $\mathrm{n}^{\circ}$ 1.111, no bairro Funcionários (região geograficamente 'central' e socialmente 'nobre' de Belo Horizonte), após passar o dia todo na Unidade Gestora de Monitoração Eletrônica da Secretaria de Estado de Defesa Social - UGME/SEDS acompanhando os trabalhos de atendimento aos monitorados.

Nos períodos compreendidos entre: 2 e 16 de junho de 2013, 11 a 31 de agosto de 2013 e 18 a 30 de novembro de 2013; referentes, respectivamente, à segunda, terceira e quarta incursões do trabalho de campo, geralmente, de segunda a sexta-feira, na parte da manhã e no período da tarde ia à UGME/SEDS, ou à $14^{\mathrm{a}}$ Vara Criminal de Belo Horizonte - VCBH para ler processos e/ou realizar entrevistas, quando não tinha que me deslocar até a Cidade Administrativa, ao Barreiro (bairro onde está localizada a sede do MPMG), ou até mesmo à UFMG - campus Pampulha, para realizar entrevista com outros interlocutores. Durante a semana, à noite, ia ao Instituto ALBAM, acompanhar a realização dos grupos reflexivos com homens autores de violência doméstica, com exceção das quintas-feiras, pois nesse dia não tinham grupos agendados (aconteciam as reuniões metodológicas organizadas pela equipe). Nas manhãs de sábado, seguia a mesma rotina, pois aconteciam, quatro grupos (um com mulheres e três com homens).

Por ocasião daquela primeira visita, fui recebido por uma das coordenadoras que, simpática e gentilmente, me apresentou as dependências do Instituto, começando pelas salas onde aconteciam os grupos reflexivos. Conversamos um pouco sobre os trabalhos, a metodologia dos grupos. Posteriormente, viria a entrevistá-la, sendo que, no decorrer do trabalho de campo esta se tornou uma das minhas principais interlocutoras.

Começaram a chegar os participantes do grupo de homens. Geralmente, eles se reuniam na porta do prédio, onde ficavam conversando até a hora de começar o grupo. Depois interfonavam, um dos funcionários abria a porta e eles subiam até o $1^{\circ}$ andar, onde ficam as salas do Instituto. Eram recebidos por algum dos mediadores e já se dirigiam à sala designada para a sessão. Enquanto não começava, aproveitavam para tomar um cafezinho, ir ao banheiro, ver alguma questão (de encaminhamento burocrático) pendente etc. 
Quando deu a hora (por volta das 19h15), acompanhei os mediadores até a sala onde se encontravam aproximadamente nove participantes. Fui apresentado como 'pesquisador' que estava estudando a monitoração eletrônica dos 'Maria da Penha'. A acolhida foi tranquila. Daqui a pouco, chegou mais um participante e sentou-se ao meu lado. Seu nome era Herculano, devia ter aproximadamente uns 40 anos de idade, era seu último encontro $\left(16^{\circ}\right)$. Do meu outro lado, estava Leonardo, aproximadamente 30 anos, era seu primeiro dia no grupo. Então, a mediadora pediu a Herculano que nos apresentasse como era a dinâmica do grupo.

A primeira coisa que Herculano disse foi que não era 'Maria da Penha' e que estava ali porque tinha agredido fisicamente a filha, tentando corrigi-la. A maioria dos participantes respondia por violências intrafamiliares, porém não necessariamente violência doméstica contra suas respectivas companheiras. Apenas um participante estava sendo monitorado com tornozeleira eletrônica e era visto com 'respeito' pelos outros participantes, como se considerassem sua situação ainda pior com relação aos demais. Segundo Herculano:

(...) no primeiro dia que eu cheguei aqui eu fiquei meio (...) perdido, e preocupado ao mesmo tempo, né? Porque eu não sabia o que ia acontecer comigo, envergonhado pela situação, eu... eu fui me acostumando mais na terceira, na quarta vez, aqui você vai ouvindo os acontecimentos de cada um, um pouquinho da história de vida de cada um, aí você vai vendo que não é só você que tem problemas.

O tom da fala de Herculano era 'aconselhativo', no sentido de orientar Leonardo, que estava chegando aquele dia, e a mim, um elemento estranho ao/no grupo, pois não havia sofrido alguma determinação judicial para estar ali participando do grupo, como era o caso dele e de todos os demais homens presentes.

Herculano disse, então, qual era a principal regra de convivência do grupo: "o que é falado no grupo fica no grupo". Todos concordaram, acenando positivamente com a cabeça. Perceba o/a leitor/a que entre os participantes, à medida que iam criando um vínculo de solidariedade, estes passavam a cativar uma ética própria aos membros do grupo. Os novos participantes deviam se adequar à regra, caso contrário procurar meios para mudar de grupo e horário. Geralmente, os grupos eram formados por homens na faixa etária de 20 a 50 anos, com diferentes históricos criminais (p. ex. torcidas organizadas, roubos e danos menores ao patrimônio, violências intrafamiliares, 'Maria da Penha', brigas de vizinhos etc.). Herculano 
disse a Leonardo: “(...) aqui você vai poder ter só duas faltas justificadas, (...) o bom é ir direto para acabar logo. Você vai gostar muito, sua mente vai se abrir, você vai se sentir outra pessoa. É isso aí”.

De repente, entrou na sala Juvenal, um jovem de aproximadamente 25 anos, estava visivelmente alcoolizado, chegou conversando alto interrompendo a fala de Herculano. Um dos moderadores o convidou a se retirar da sala. Todos perceberam, alguns riram, outros ficaram desinquietos, quase comovidos com a situação do companheiro que, certamente, devia estar passando por algum problema para ter chegado naquela situação. Enquanto isso, a moderadora prosseguiu com a dinâmica do grupo.

Herculano disse que se sentia injustiçado por estar ali. A expressão de solidariedade era evidentemente perceptível nos semblantes dos demais homens. Porém, concluiu sua fala dizendo que, apesar de cumprido a contragosto os dezesseis encontros, percebeu alguma mudança em sua 'forma pessoal de ver o mundo', de 'se relacionar com as outras pessoas', que conseguiu 'derrubar preconceitos em relação a negros, mulheres e gays'; e começou a chorar...

A moderadora, também emocionada com a situação, agradeceu as palavras de Herculano. Em seguida, pediu a Leonardo que se apresentasse ao grupo. Leonardo disse que estava ali porque ameaçou matar a namorada, mas não matou, 'só ameaçou' (!). Nas palavras dele:

(...) eu falei que ia matar a minha namorada, minha ex... ex-namorada, falei essas palavras aí (...) Eu tô aqui mais é por causa da mãe dela também, se fosse por causa dela ela não achava que eu ia matar ela não. Aí eu não mato ninguém não. (...) Eu tava tonto com a palavra que saiu da minha boca sem precisão. Eu não ia fazer isso não, ela sabe, mas foi a mãe dela que oprimiu ela para tratar com a 'Maria da Penha'. Se fosse por ela eu não estava aqui não. Tenho certeza.

Então, a moderadora perguntou a Leonardo como ele reagiria se os papéis fossem trocados e ele fosse a mulher que estivesse recebendo a ameaça. Leonardo disse que não gostaria de estar na condição de mulher, porque "como mulher é ruim demais". Todos riram, meio que banalizando a situação, ou seja, um 'homem macho' que se colocava no lugar da mulher, mesmo que para avaliar seu comportamento, eles consideravam isso complicado pois feria a masculinidade. Leonardo colocou o caso de outra forma: como ele se sentiria sendo 
ameaçado por alguém; disse que daria queixa na polícia, que denunciaria. "Eu com a mente que eu tenho? [Diria:] 'Mata então. Vê se mata'. (...) Estufou o peito tipo assim: 'atira, então!'”.

Passaram a discutir um caso no qual a mulher foi ameaçada várias vezes pelo exnamorado, registrou diversas ocorrências e nada foi feito, até que um dia, mesmo sob ameaça a mão armada, ela desacreditou que o ex fosse concretizar a ação e acabou sendo assassinada. Referiram-se ao caso de Maria Islaine, que foi assassinada pelo ex-companheiro com 'tiros a queima roupa' em seu local de trabalho naquele mesmo ano.

Segundo um dos participantes, o caso deveria ser analisado da seguinte forma: “(...) nós tá aqui dentro da sala, eu viro pra ele e digo: 'vou te matar!'. Aí ali ele pode desacreditar e tudo, mas eu tô com um revólver aqui na sua cara, 'vou te matar'. O quê você vai fazer? Você vai duvidar?”. Já segundo outro participante, a culpa pela morte foi da própria mulher:

Ele já foi pra matar. Beleza. Mas se ela não tivesse feito o que fez, eu acho que haveria uma chance ainda. (...) Entendeu? Haveria uma chance ainda. Que ele chamou... cê vê a filmagem... ele chamou ela pra conversar antes e ela não quis. (...) Ele jogou a arma em cima, pra mim ela se comportou mal, porque ela deveria recuar, ela não deveria ter batido de frente, enfrentado ele do jeito que enfrentou. Entendeu? (...) Ela deveria ter recuado.

Outro participante concordou: "Bateu de frente mesmo!” E lembrou: "Ele já tava na 'Maria da Penha', não tava?”. Já para outro: "Eu acho que foi excesso de confiança dela, às vezes um casal se acostuma muito um com o outro e, sei lá, 'acho que você é um frouxo'. Pensou que não ia fazer; "nunca fez nada comigo, não vai fazer isso'”. E comparou com o seu próprio caso:

(...) a minha [mulher] me ameaçou várias vezes então, eu achei que ela nunca ia fazer isso que ela fez. Excesso de confiança. (...) Eu não sei, dá pra gente pensar um montão de coisa. Uma coisa que eu fico pensando é que, talvez, esse cara já tivesse ameaçado tanto ela que chega uma hora que ela já devia estar tão paralisada que ela falou: 'ah, chega, né! Vou caminhar'. Porque é muito complicado sim. (...) eu acho que isso a gente tem que analisar caso a caso. 
Ainda sobre o mesmo caso considerado emblemático e trazido para discussão no grupo, a moderadora ponderou que a mulher já tinha registrado nove boletins de ocorrência na polícia. E um dos participantes afirmou: "Fizesse o décimo. (...) Ela provocou! Ela botou a mão na cintura. Uma pessoa que já tinha feito nove boletins de ocorrências, né gente”. Diante daquele e dos outros comentários dos participantes, a moderadora ponderou ao final que um 'simples' “eu só falei que ia matar", poderia gerar um desconforto tão grande na pessoa, que por si só já é uma situação de violência ('mesmo não sendo física'), que poderia desencadear uma depressão e gerar uma série de outras consequências. Um dos participantes concordou e disse:

\begin{abstract}
Deve causar um trauma psicológico, porque a pessoa fica assim: 'Pôxa ele me ameaçou', aí amanhã passa perto da pessoa e fala 'Poxa! Será que ele vai fazer aquilo agora?'. A pessoa às vezes está na cozinha fazendo uma comida, 'Será que ele vai chegar aqui e vai fazer isso?' Vai para a casa da mãe e do pai 'E se ele vier atrás aqui e fazer aquilo que ele falou?'. Então eu acho que fica um trauma pra pessoa, um trauma psicológico. A verdade é essa, ameaçar ela é pior porque deixa trauma, deixa sequela.
\end{abstract}

A discussão encaminhou-se, então, para a questão da impunidade e da não efetividade da Justiça. Os participantes começaram a fazer críticas também à Lei 'Maria da Penha' ("essa leizinha"), às medidas protetivas etc. Um dos participantes disse que "em briga de marido e mulher, ninguém mete a colher" e foi repreendido pela moderadora. Outro disse que "não aprendi a respeitar mulher" e que a 'mulher dele' era "reserva e preserva", no sentido de que, com garotas de programa ele faz outras coisas que com que a 'mulher dele' ele não faz, mas ele a satisfaz porque tem receio de que ela busque isso com outro homem.

A moderadora retornou o tema da discussão anterior, sobre o se colocar no papel de mulher. Todos se referiram às mulheres como objeto destinado ao/à: sexo, casa, comida, roupa limpa, filhos etc. Tive que sair com mais ou menos 1 h e 30 minutos de grupo, já estava no final, mas não pude esperar os últimos minutos, uma vez que fui conversar com o único participante monitorado com tornozeleira eletrônica. Chamo de 'conversa', porque apesar de estruturada, não correspondia a uma entrevista nos moldes metodológicos tradicionais da técnica de entrevista. Procurava sempre deixar meu interlocutor o mais à vontade possível, conversávamos sobre outros assuntos até chegar à questão da monitoração. Com o passar do tempo, ia conquistando sua confiança. Alguns voltaram ao Instituto depois de retirada a tornozeleira me 
procurando para contar sobre como estavam se sentido no pós-monitoração. Ressalte-se que a equipe do Instituto ALBAM foi sempre muito prestativa e atenciosa em me possibilitar o acesso aos monitorados, ao que sou bastante grato.

Segui esse mesmo protocolo em todos os demais grupos dos quais pude participar durante o trabalho de campo, um total de dez grupos com homens; exceto quando haviam muitos monitorados participando dos grupos (p. ex. mais de três); mas sempre participava um pouco do grupo (mais ou menos $1 \mathrm{~h}$ de grupo) e depois me dirigia a outra sala do Instituto para conversar em particular com os monitorados, um de cada vez. Tiveram dias que consegui conversar com até cinco monitorados em um único período. Ao todo, conversei com 23 monitorados. Conversei, também, com dois ex-monitorados, porém como a conversa foi mais informal, não foram gravadas. Todavia, são consideradas neste texto no que concerne à análise do material anotado no caderno (ou diário) de campo.

\section{CONJUGANDO ABORDAGENS E MÉTODOS DE INTERVENÇÃO COM HOMENS AUTORES DE VIOLÊNCIAS CONTRA MULHERES: GRUPOS REFLEXIVOS DE GÊNERO E MONITORAÇÃO ELETRÔNICA COM TORNOZELEIRAS}

Uma nota se faz necessária neste momento. Optei por iniciar o texto apresentando a dinâmica dos grupos reflexivos com homens autores de violências, como acontecem na prática e, para tanto, escolhi logo o primeiro grupo do qual participei no Instituto ALBAM, basicamente por dois motivos: o primeiro, porque estava recém-chegado ao campo, conhecia pouco da metodologia de intervenção com homens agressores por meio do trabalho em 'grupos de reflexão de gênero', e essa aproximação/distanciamento me permitiu observar densamente e anotar atentamente cada detalhe, inclusive trechos de falas dos participantes; o segundo se deve ao fato de que este foi um dos poucos grupos que pude ou consegui participar quase integralmente, pois tinha apenas um participante monitorado para conversar posteriormente.

Não é meu intuito aqui dissecar a literatura teórica e metodológica sobre intervenção 
com homens em grupos ${ }^{3}$, mas a de apresentar etnograficamente como e em que medida esses grupos têm proporcionado que sejam trabalhadas preventiva e pontualmente diversas questões (tais como: gênero, masculinidade, violência, direitos etc.) com homens autores de violência intrafamiliar e doméstica em Belo Horizonte; passo, a seguir, a uma breve contextualização desse trabalho naquela localidade e, na sequência, busco analisar algumas questões que emergiram das conversas com os participantes monitorados com tornozeleiras eletrônicas.

Lembro ao/à leitor/a que, neste caso, tratam-se os grupos reflexivos de uma medida aplicada pelo juiz ao agressor nos casos judicializados de violências intrafamiliares e domésticas. Interessou-me, portanto, compreender se a aplicação da monitoração eletrônica conjugada com a obrigatoriedade em frequentar tais grupos tem proporcionado de maneira pontual algum tipo de mudança, transformação ou subversão em termos do trabalho com essas 'masculinidades violentas'; bem como a perspectiva dos agentes envolvidos (sobretudo, dos próprios monitorados) com relação ao processo como representam e simbolizam essas violências e a noção de direitos a partir de suas histórias e trajetórias individuais.

Convém pontuar, de antemão, que as primeiras experiências nacionais de atenção aos homens a partir de uma perspectiva de gênero datam de meados dos anos 80. Entretanto, somente dez anos mais tarde surgiram ações destinadas ao público masculino por iniciativa de organizações não governamentais brasileiras e instituições públicas da saúde coletiva que, embasadas em perspectivas feministas, embora sofrendo resistências dos movimentos, vêm discutindo assuntos como: saúde sexual e reprodutiva, paternidade, violência entre homens e contra mulheres etc. (OLIVEIRA e GOMES, 2011).

As primeiras intervenções específicas junto a homens autores de violência contra mulheres datam do ano de 1998, sob a forma de grupos de reflexão ${ }^{4}$, no contexto das

\footnotetext{
${ }^{3}$ Sobre isto já se ocuparam diversos trabalhos de pesquisadores/as das ciências da saúde e da psicologia, lembrando que realizo também alguma reflexão sobre o tema em: CAIXETA MACIEL, Welliton. Os "Maria da Penha": uma etnografia de mecanismos de vigilância e subversão de masculinidades violentas em Belo Horizonte. (Dissertação de Mestrado). Programa de Pós-Graduação em Antropologia Social da Universidade de Brasília, 2014. Ver também: NOTHAFT, Raíssa Jeanine; BEIRAS, Adriano. O que sabemos sobre intervenções com autores de violência doméstica e familiar?. Revista Estudos Feministas, Florianópolis, v. 27, n. 3, e56070, 2019.

${ }^{4}$ Segundo Bárbara Musumeci Soares, esses grupos de reflexão eram “(...) concebidos como espaços propícios à assunção de responsabilidades, à ampliação do autoconhecimento, à vocalização de experiências e valores associados à subjetividade masculina, à expansão de horizontes, à transformação da autoimagem e ao reenquadramento das perspectivas individuais. Em duas palavras, um processo de 'reflexão responsabilizante'. Nem a medicalização indulgente, nem o confronto inquisitório, mas uma oportunidade, para que os homens pudessem se comprometer em construir, com suas parceiras, presentes ou futuras, relações mais cooperativas e solidárias, a partir do reconhecimento da violência praticada" (ACOSTA et. al., 2004: 9).
} 
organizações não governamentais: Instituto Papai, do Recife; Instituto Promundo, Instituto de Pesquisas Sistêmicas e Desenvolvimento de Redes Sociais - Instituto Noos e Núcleo de Atenção à Violência - NAV, do Rio de Janeiro; e o Pró-Mulher, Família e Cidadania, de São Paulo. Na esfera governamental, esse pioneirismo coube ao Centro Especial de Orientação à Mulher Zuzu Angel - CEOM, de São Gonçalo/RJ, que começou a atender esse público em 1999, realizando atendimentos individuais ou em grupos reflexivos de gênero. Somente em 2009, em Nova Iguaçu/RJ, foi implementado o primeiro centro de reeducação de agressores, tal como previsto pela Lei 'Maria da Penha'. Este foi denominado 'Serviço de Educação e Responsabilização para Homens Autores de Violência de Gênero (SerH), uma parceria da Secretaria Municipal de Assistência Social e Prevenção da Violência em Nova Iguaçu com o Instituto Noos. Segundo Fernando Acosta, idealizador do projeto, o objetivo fundamental era o de “(...) promover o compromisso dos homens para desenvolver novas formas de relações interpessoais, evitar e prevenir atitudes violentas no meio familiar" (PORTAL DA VIOLÊNCIA CONTRA A MULHER, 2009).

Com relação às intervenções direcionadas à prevenção e atenção da violência de gênero, intrafamiliar e doméstica, Saffioti (2004: 68) pontua que:

\begin{abstract}
As pessoas envolvidas na relação violenta devem ter o desejo de mudar. É por esta razão que não se acredita numa mudança radical de uma relação violenta, quando se trabalha exclusivamente com a vítima. Sofrendo esta algumas mudanças, enquanto a outra parte permanece o que sempre foi, mantendo seus habitus, a relação pode, inclusive, tornar-se ainda mais violenta. Todos percebem que a vítima precisa de ajuda, mas poucos veem esta necessidade no agressor. As duas partes precisam de auxílio para promover uma verdadeira transformação da relação violenta.
\end{abstract}

Segundo Lima e Büchele (2011: 729-730), “(..) o envolvimento dos homens na prevenção, atenção e enfrentamento à violência contra as mulheres permanece incipiente (...), contudo, a promulgação da Lei 'Maria da Penha' trouxe novos olhares e possibilidades para esse debate". O art. 35 dispõe que o Estado poderá criar e promover, no limite das respectivas competências, centros de educação e de reabilitação para os autores de violência. E o art. 45 orienta que "nos casos de violência doméstica contra a mulher, o juiz poderá determinar o comparecimento obrigatório do agressor a programas de recuperação e reeducação" (BRASIL, 2006). Todavia, a lei não especificou como deve ser a estrutura e organização dos centros de 
atendimento aos 'agressores', nem como devem ser as intervenções de 'educação e reabilitação' ou 'recuperação ou reeducação'.

Segundo Leite e Lopes (2013: 30), “(...) há, ainda, polêmica sobre qual é o melhor momento processual para se aplicar a participação em grupo reflexivo. Falta consenso, sobretudo, se é possível aplicá-la na modalidade de medida protetiva, pois muitos entendem que estaria havendo antecipação da pena (...)". Pontuam os referidos autores que, na prática, a participação em grupos reflexivos tem sido aplicada nas seguintes hipóteses: i) como medida protetiva de urgência: “(...) tal como o afastamento do agressor do lar, proibição de contato e aproximação com a vítima, suspensão de visitas aos dependentes e prestação de alimentos provisionais, (...), é possível, segundo a lei, aplicar outras modalidades que o juiz entender adequadas, como a participação em grupos de caráter educativo"; ii) como condição para a concessão de liberdade provisória: “(...) com ou sem fiança, quando houver prisão em flagrante ou preventivamente no contexto da Lei Maria da Penha"; iii) como condição para a suspensão condicional do processo: “(...) prevê o monitoramento do acusado por dois a quatro anos e não impede a aplicação de condicionantes como forma de acompanhamento do acusado durante o período probatório, sendo possível, portanto, a participação em grupo reflexivo como condição de acompanhamento ao período probatório"5; iv) na condenação como substituição por pena restritiva de direito: no entanto, “(...) um número bastante restrito de processos de LMP chega à condenação, então, a participação em grupos raramente se dá nesse contexto" (p. 31-32) .

Em Belo Horizonte, quando da realização da pesquisa de campo, os 'Grupos Temáticos Reflexivos sobre violência doméstica e intrafamiliar' estavam previstos no 'Projeto Temático Reflexivo sobre Violência Doméstica e Intrafamiliar' implementado pelo Programa Central de Acompanhamento às Penas e Medidas Alternativas - CEAPA, da Coordenadoria Especial de Prevenção à Criminalidade - CPEC, da Secretaria de Estado de Defesa Social - SEDS do Governo do Estado de Minas Gerais; e consistem na “(...) participação de homens e mulheres em situação de violência doméstica e intrafamiliar, sejam como autores ou vítimas, em grupos reflexivos que têm como pano de fundo a temática de gênero".

\footnotetext{
${ }^{5}$ Convém lembrar, no entanto, que, ao declarar a constitucionalidade do art. 41, da Lei 'Maria da Penha', o Supremo Tribunal Federal posicionou-se contra a aplicação dos institutos despenalizadores da Lei $\mathrm{n}^{\circ}$ 9.099/95 aos crimes praticados com violência doméstica, sendo a suspensão condicional do processo um deles; conforme pontuado anteriormente.

${ }^{6}$ Perceba o/a leitor/a que as hipóteses elencadas apontam para o paradoxo da penalização vs. a possibilidade da administração institucional dos conflitos.
} 
Tal prática foi iniciada, em Minas Gerais, pelo Tribunal de Justiça de Minas Gerais, por meio do Juizado Especial Criminal de Belo Horizonte, nos eixos 'Drogas' e 'Violência de Gênero e Intrafamiliar', anterior ao advento da Lei 'Maria da Penha'. A partir de 2006, o Programa CEAPA tornou-se parceiro nesta ação, possibilitando a contratação, via licitação, de instituições parceiras para realização dos grupos reflexivos. No momento de realização do trabalho de campo, os 'Projetos Temáticos' contemplavam os seguintes eixos de atuação: 'Drogas', 'Violência Doméstica e Familiar', 'Meio Ambiente', 'Trânsito' e 'Porte Ilegal de Armas'.

Atendo-se ao 'Projeto Temático Reflexivo sobre Violência Doméstica e Intrafamiliar'7, é importante destacar que, para a realização deste trabalho, o Estado mineiro, por meio da Secretaria de Estado de Defesa Social - SEDS, e o Poder Judiciário contavam, desde 2006, com a parceria do Instituto Mineiro de Saúde Mental e Social - Instituto ALBAM ${ }^{8}$. Esta instituição, desde 2005 (anterior à Lei 'Maria da Penha', portanto), com a idealização do Programa ANDROS, atende a 'homens que exercem violência contra mulheres' e, complementarmente, atende mulheres em situação de violência. O programa, que em 2008 tornou-se uma política pública, funciona de forma conjugada à prática judicial de encaminhamento para 'grupos de reflexão de gênero'.

Com relação aos 'Grupos Reflexivos', são previstos em dois modelos: para homens: 16 (dezesseis) encontros com homens autores de violência doméstica e intrafamiliar contra mulheres, realizados semanalmente com duração de duas horas cada e com participação aproximada de 16 homens; e para mulheres: 12 (doze) encontros com mulheres envolvidas em situação de violência doméstica e intrafamiliar (vítimas e autoras de violência no mesmo grupo), com a mesma periodicidade, duração e número aproximado de participantes.

De acordo com a metodologia aplicada pelo Instituto ALBAM, os grupos de homens são abertos e coordenados por dois mediadores, sendo um homem e uma mulher; enquanto que os grupos de mulheres são fechados, ou seja, iniciam e finalizam com as mesmas participantes (até o segundo encontro é permitido a entrada de novas participantes), sendo coordenados por duas mulheres. Segundo o supervisor metodológico do Instituto, este tipo de grupo “(...)

\footnotetext{
${ }^{7}$ Naquele momento, encontrava-se em funcionamento na Capital e nas seguintes cidades da região metropolitana de Belo Horizonte: Betim, Contagem, Ribeirão das Neves e Santa Luzia.

${ }^{8}$ Organização não governamental sem fins lucrativos, fundada em 1998 e considerada instituição de interesse público pelo Município de Belo Horizonte. Desenvolve intervenções psicossociais pautadas principalmente por técnicas grupais, tendo como eixo teórico a perspectiva feminista de gênero.
} 
privilegia os vínculos grupais, é importante que as mulheres se sintam em uma roda de cumplicidade (...) a cada grupo um contrato é construído a partir de uma dinâmica e tópicos tais como: horário, atrasos permitidos, uso de celulares e faltas são uma construção coletiva do grupo'.

No caso dos grupos de homens, os participantes são encaminhados a partir de ações tipificadas tanto na Lei 'Maria da Penha' ou na Lei n’ 9.099/95 (torcidas organizadas, brigas de rua, agressões a filhos etc.). Segundo Lattanzio e Barbosa (2013: 88-89) ${ }^{9}$, essa dupla via de fontes de encaminhamento

(...) tem possibilitado, por um lado, que os homens que cometeram outras violências reflitam de forma mais contundente sobre a violência contra a mulher em seus vários aspectos (físico, psicológico, sexual...), a desigualdade de poder nas relações que estabelecem, entre outros aspectos. De outro lado, possibilita aos homens que cometeram violência contra a mulher ampliar o escopo de reflexões a partir da experiência dos demais, trazendo, com mais frequência, temas como a paternidade e os modos dialogais de resolução de conflitos. Tal decisão de mesclar os grupos, enfim, tem possibilitado, principalmente, a percepção, cada vez mais nítida, de que as diversas violências masculinas têm uma raiz comum relacionada ao gênero.

Segundo o supervisor metodológico do Instituto ALBAM, naquela ocasião, as intervenções podem ser de dois tipos: combativas, no que visam colocar 'em xeque as justificativas para a violência e [explicitar] a desigualdade de poder e os privilégios decorrentes do machismo'; ou intervenções que objetivam o 'cuidado e a escuta desses homens e do sofrimento psíquico ligado à rigidez das identidades'; sendo que 'é no difícil manejo entre esses dois tipos que reside a possibilidade de êxito nas intervenções'.

\footnotetext{
9 Respectivamente, o supervisor metodológico e uma das coordenadoras do Instituto ALBAM, quando da realização do trabalho de campo. A referência de leitura foi indicada por uma das profissionais do Psicossocial do Instituto, tendo em vista que o trabalho na instituição tem orientado reflexões práticas e teóricas de seus membros. Esta publicação, por exemplo, foi realizada em parceria entre o Instituto ALBAM e o Instituto ISER, do Rio de Janeiro, que também realiza trabalho no tema.
} 


\section{POSSIBILIDADES E DESAFIOS DA INTERVENÇÃO COM HOMENS AUTORES DE VIOLÊNCIAS CONTRA MULHERES EM BELO HORIZONTE}

A partir das entrevistas com gestores públicos e com profissionais do serviço 'Psicossocial', me pareceu que existir certo consenso quanto à atribuição de importância e do reconhecimento ao trabalho de grupos reflexivos de gênero desenvolvido com homens autores de violência contras mulheres em Belo Horizonte, ainda que nem todos os atores institucionais concordassem com relação à aplicação conjugada com a medida de monitoração eletrônica.

Na visão dos/as representantes do Judiciário, do Governo do Estado e do Ministério Público entrevistados/as essa questão mostrou-se de certo modo pacificada. Chama atenção, no entanto, a forma como os juízes das Varas especializadas em violência doméstica da Capital encaminham os casos de monitoração eletrônica aos grupos reflexivos, bem como a forma como constroem os critérios (objetivos?) para tal; ainda que, na visão de uma das gestoras da Coordenadoria de Políticas para Mulheres, da Secretaria de Desenvolvimento Social de Minas Gerais, todos os homens monitorados por violência intrafamiliar e doméstica contra mulheres devessem passar pelos referidos grupos. Deparamo-nos com a seguinte questão: o que deveria ser uma medida protetiva, talvez esteja, na prática, sendo utilizada como 'punição'. Este argumento é perceptível nos trechos de fala transcritos a seguir.

\footnotetext{
"Às vezes, a gente coloca a monitoração. Às vezes, a gente coloca e manda frequentar 'cursos', dependendo da gravidade, caso a caso, às vezes só monitoração. (...) $\mathrm{Na}$ 'Maria da Penha' são os casos que a gente acha que precisa de uma fiscalização maior, porque não precisa prender o indivíduo. Aí é subjetivo, é caso a caso, não tem como taxar esse caso como de monitoração. Eu vou ver o processo, vou ver se eu entendo se a vítima está em risco e se pode uma medida mais branda ser aplicada ou não. (...) O primeiro critério objetivo principal é o descumprimento das medidas deferidas anteriormente, que ele já foi intimado e está descumprindo, aí eu vou ver o grau de descumprimento, o que ele está fazendo? Ele está indo lá e ameaçando a vítima? Está indo lá e agredindo a vítima? O limiar entre ameaça e agressão é muito tênue também, porque quem está indo lá e ameaçando hoje pode estar agredindo amanhã, entendeu? Mas o objetivo principal é o descumprimento das medidas, aí eu vou analisar no processo de que forma que ele descumpriu" 10 .

“(...) a recomendação nossa é que $100 \%$ dos homens que são monitorados estejam inseridos nesses grupos, no acompanhamento reflexivo, achamos importantíssimo que eles participem lá não só pela questão de quantos são monitorados"11.
}

\footnotetext{
${ }^{10}$ Entrevista com Gestor 3 (TJMG), realizada em 12 de junho de 2013.

${ }^{11}$ Entrevista com Gestora 4 (SEDES), realizada em 13 de junho de 2013.
} 
Contudo, ainda que tais iniciativas possam reverberar para além dos espaços institucionais, não temos subsídios empíricos para afirmar que a aplicação da medida de monitoração eletrônica conjugada com os grupos reflexivos a homens autores de violência contra mulheres seja capaz de produzir algum tipo de mudança simbólica e/ou comportamental nesses sujeitos, conforme pontuou um/a dos/as interlocutores/as. Cito um trecho de sua fala:

(...) sobre como tem sido o retorno dessas pessoas quando elas vêm retirar o equipamento [de monitoração], e conversando com uma das psicólogas (...) ela me disse que tem recebido alguns [monitorados] que têm comentado sobre a participação nos grupos e que estão dispostos a mudar o comportamento a partir de agora. Mas isso a gente só vai saber depois que começar medir os dados novamente dessas pessoas elas começaram a reentrar por causa de violência doméstica no sistema prisional? (...) Só aí a gente vai saber se esse momento que ele teve [no grupo e na monitoração] conseguiu, de alguma forma, desestimulá-lo a praticar a violência doméstica ${ }^{12}$.

Convém ressaltar que não existe um perfil exato (social, psicológico ou criminal) dos homens encaminhados pelo Judiciário para os serviços de atendimento aos homens autores de violência intrafamiliar naquela localidade, conforme pontuou uma das profissionais do Instituto ALBAM. Destaca, porém, que com a Lei 'Maria da Penha' tem-se conseguido abraçar um número maior de homens autores de violência contra mulheres, coisa que, segundo ela, não acontecia anteriormente.

Dizer [sobre] perfil é complicado porque se existe um perfil ainda está muito relacionado ao recorte econômico, sabe, de vulnerabilidade social [...] Mas o que eu acho novo é que a gente começa a perceber a vinda de pessoas que tem um acesso, vamos dizer, econômico e cultural que antes a gente não percebia na Lei 9.099. A Lei 'Maria da Penha' acho que ela consegue chegar, do ponto de vista de aplicação da pena, a setores que antes nunca viriam, por exemplo, para o cumprimento de prestação de serviço à comunidade porque pagariam uma pena pecuniária, e a Lei 'Maria da Penha' nesse sentido ela é mais rígida ${ }^{13}$.

É interessante observar a maneira como os homens autores de violências chegam aos grupos reflexivos de gênero, o que não se distancia muito da forma como os monitorados

\footnotetext{
${ }^{12}$ Entrevista com Gestor 10 (SEDS), realizada em 26 de novembro de 2013; grifos nossos.

${ }^{13}$ Entrevista com profissional do serviço 'Psicossocial' 5, realizada em 22 de novembro de 2013; grifo nosso.
} 
chegam à UGME. Geralmente, não são devidamente informados das medidas (cautelares e protetivas) determinadas em juízo nem como deverão proceder para cumpri-las efetivamente, o que pode contribuir para resistências por parte desses homens ao longo desse processo ou mesmo para novas reincidências em atitudes violentas.

É importante destacar, por outro lado, como a posição de 'vítima' é performatizada por esses sujeitos e, comparativamente, como as mulheres (agredidas) assumem outro tipo de postura (mais ativa) ao comparecerem à UGME quando vão buscar seu aparelho de monitoração. É evidente como a referida política tem não apenas corroborado para uma espécie de empoderamento dessas pessoas, mas também invertido a lógica de controle; a mulher não apenas decide se quer se submeter à monitoração, mas detém para si, em parte, o controle da situação que anteriormente não lhe era favorável, inclusive se quer continuar a relação (com ou sem monitoração), criando mecanismos informais de negociação com relação ao cumprimento da medida. Todavia, para ambas as partes faltam esclarecimentos e/ou clareza na comunicação por parte dos agentes institucionais.

Segundo o supervisor metodológico do Instituto ALBAM, romper com a 'posição de vitimização' dos homens autores de violências tem-se mostrado um dos principais desafios para o processo de responsabilização desses sujeitos nos grupos reflexivos de gênero.

\begin{abstract}
A maior dificuldade de todas é o 'vitimismo masculino', todos que chegam aqui são 'vítimas', 'vítimas' da lei 'Maria da Penha'; porque não foram ouvidos na delegacia; porque não sei o que - e eles têm um pouco de razão, entende? Não estão totalmente sem razão, mas não é também 'vítima'... e o complexo é esse, porque se você ignorar tudo que eles estão falando, né, eles também não vão fazer um vínculo com você pra conseguir ter liberdade de falar no grupo. Então, a principal [dificuldade] é ele saírem da posição de vitimização. E a outra dificuldade é eles entenderem que a mulher é um sujeito também, não é no sentido estereotipado de que eles entendem, mas no sentido da dificuldade de ver que na mulher também há desejo (...) que causa sofrimento, e eles: 'isso é normal, isso é assim mesmo'; 'eu sempre fui um pai de família honesto, trabalhador, não tem porque... automaticamente é pra ela gostar de mim'. Então essa questão do reconhecimento do outro, o reconhecimento verdadeiro do outro, isso é muito difícil também.
\end{abstract}

O estigma de ser 'batedor de mulher' e/ou ser 'Maria da Penha', também mexe bastante com a identidade desses sujeitos que, em sua maioria, procuram desconstruir individual e socialmente essa imagem negativa nos grupos, conforme relatou uma das interlocutoras que 
também é moderadora de grupos reflexivos de gênero.

\begin{abstract}
No próprio grupo aquele que não é 'Maria da Penha' já fala logo: 'Eu não sou 'Maria da Penha' não'. Então, tem isso e eles também falam como eles sofrem discriminação lá fora porque, de alguma forma, a Lei 'Maria da Penha' trouxe também um tipo de constrangimento social do 'homem que bate na mulher'. E aí, aqueles que foram presos trazem muito sobre a violência dentro da prisão... [...] eles relatam sim essa questão do preconceito de uma diferenciação entre eles, e quem está com monitoração eletrônica muito mais; aí eles falam de mudança de hábitos mesmo, né. O que usa bermuda pára de usar. $\mathrm{O}$ que vai pro clube não vai mais... ${ }^{14}$.
\end{abstract}

Perceba o/a leitor/a que existe uma negação muito forte da dignidade daquele que usa a tornozeleira eletrônica, com as respectivas consequências em relação aos direitos.

[...] nesse dia ela pegou virou pra mim e falou pra mim: 'vamos conversar hoje?' Eu falei: 'vamos'. Danada da vida. Só que eu não estava usando ela [a tornozeleira]. No dia que ela pegou [o equipamento de monitoração - UPR], (...) eu parei pra conversar com ela e começamos a discutir, até financeiramente, esse negócio de dinheiro, aí eu peguei arranquei o dinheiro e joguei [no chão]. Só que, no que eu joguei, parou a viatura e achou que eu tava era assaltando ela, a viatura do BOPE, a Polícia Civil: 'Perdeu, perdeu!' Eu falei: 'perdeu o que senhor?' 'Tá assaltando a moça!' 'Não, isso é dinheiro que eu joguei para dar pra ela, ela tá achando que eu to duro. Eu tenho dinheiro'. Aí ela falou: 'inclusive ele tem 200 metros. Ele é 'Maria da Penha' '. O cara falou: 'Ah! Você é Maria da Penha, você tá preso, tem 200 metros e quebrou o cumprimento, você tá preso agora'. Eu fiquei três dias no sereno só; aí o juiz pra me liberar mandou eu escolher, eu ficava na cadeia pagando os três meses ou me soltava e jogava nisso aqui [tornozeleira]. Foi tipo um acordo que ele fez com o advogado, quando ele requereu na hora lá, pôs isso aqui [a obrigatoriedade em frequentar os grupos reflexivos] e esse negócio aqui [a tornozeleira eletrônica] pra mim não ficar preso. (...) O grupo [reflexivo] e a tornozeleira, são as duas coisas. Nessa brincadeira já tamos prejudicados em quase $\mathrm{R} \$ 10$ mil reais ${ }^{15}$.

$\mathrm{Na}$ fala acima, a interação com a agredida pode sugerir, talvez, alguma manipulação dela e má compreensão do caso por parte dos policiais. Todavia, faltam elementos para afirmamos criteriosamente isso; a interação com a ex-mulher precisava ser melhor esclarecida. Esse mesmo trecho de fala e os dois citados a seguir se referem a entrevistas com monitorados/participantes do segundo e terceiros grupos reflexivos que assisti no Instituto

\footnotetext{
${ }^{14}$ Entrevista com profissional do serviço 'Psicossocial' 5, realizada em 22 de novembro de 2013; grifos nossos.

${ }^{15}$ Entrevista com monitorado 1, realizada em 15 de junho de 2013. Participante do grupo reflexivo n. ${ }^{\circ} 2$; grifo nosso.
} 
ALBAM e ilustram, ainda, a resistência e a situação desses homens face ao cumprimento das medidas judiciais. Com relação ao primeiro, por exemplo, seria seu quinto encontro se já não tivesse faltado a dois deles.

(...) eu nunca bati em uma mulher, nunca encostei em mulher, eu falo pro oficial uma coisa: 'se for fazer uma coisa eu faço direito, mato de uma vez e acabou o problema'. Mas hoje eu falo com você, me arrependo amargamente de ter pegado o revólver lá em casa (...). Não só pela palhaçada que deu esse negócio de cadeia, não por isso, porque um dia minha filha ia chegar pra mim e falar: 'você matou minha mãe!' E jogar na minha cara isso. Como não tenho mãe desde os meus oito anos, entendo, eu sei como é que é, falta de pai é fácil, de mãe não. ${ }^{16}$

(...) eu não tinha colocado isso [tornozeleira] aí não, aí eu peguei um ônibus e ela pegou outro e no que ela chegou no ponto eu tinha descido no ponto, aí ela me viu e a tia dela mandou ela ir na delegacia: 'melhor você pedir medida protetiva'. O juiz mandou me recolher e mandou um mandado de prisão pra mim, aí prendeu eu, fiquei seis dias lá e só saí com esse negócio aqui [tornozeleira]. (...) Está incomodando. O que incomoda a gente é a crítica dos outros, é mal visto demais; você fica mal visto demais com isso, o povo critica muito. (...) Tipo assim: ‘que negócio é esse?' 'Você matou?' 'Você roubou?' 'Agrediu sua mulher?'. 'Não foi nada disso, foi uma discussão só'. Pra colocar é uma benção, mas pra tirar é um 'Deus nos acuda'. (...) Caleja o pé o tempo todo. (...) Cortou. Aqui tem um aço. (...) Tem que carregar igual a celular, três horas por dia. (...) Essa lei [Lei 'Maria da Penha'] não tá com nada. Ninguém gosta dessa lei não. ${ }^{17}$

Perceba o/a leitor/a que, além da insatisfação com a determinação de ambas as medidas pelo juiz, a exemplo da fala de ambos os interlocutores (o que é recorrente também na fala de outros), talvez por estarem em fase inicial de cumprimento, também não existe muita sensibilidade por parte dos monitorados com relação às questões de gênero, que se encontram naturalizadas de tal modo a não permitir com que as mesmas sejam vistas como um problema na visão desses homens. Todavia, como dito anteriormente, também não parece haver muito esforço das instituições de Justiça em esclarecer as coisas para o jurisdicionado.

Lattanzio e Barbosa (2013: 90), acreditam que “(...) os grupos reflexivos de gênero são ferramentas eficazes para intervir nas violências masculinas de forma geral, pois, em sua variedade, têm em comum a rigidez e a estereotipia no modo como exercem a masculinidade, resolvem seus conflitos, são impermeáveis ao outro e, assim, a violência aparece como

\footnotetext{
${ }^{16}$ Idem.

${ }^{17}$ Entrevista com monitorado 2, realizada em 16 de agosto de 2013. Participante do grupo reflexivo n. ${ }^{\text {3 }}$; grifos nossos.
} 
expressão desse paradoxo da identidade masculina" (p. 95).

Nos grupos reflexivos dos quais participei pude perceber que existem 'espaços para elucidação dos casos' a partir das narrativas e exposição de trajetórias de vida pessoais, porém esses, às vezes, se confundem com 'espaços de conversão'. Naquilo que têm de conversão, trazem implicações talvez negativas para a qualidade da mudança pretendida nas atitudes dos participantes com relação ao tratamento dispensado às mulheres. Percebi também que trabalhar com a responsabilização dos homens autores de violência contra mulheres por meio dos grupos reflexivos de gênero tem se mostrado um grande desafio sob o ponto de vista das masculinidades (no plural) e das violências em cena nessas ocasiões. Nesse contexto, diferentes dinâmicas são realizadas com foco na questão da identidade desses sujeitos, sendo a responsabilização apenas um dos eixos metodológicos na condução dos grupos.

Ainda de acordo com Lattanzio e Barbosa (2013: 96), “(...) o espaço para a intervenção se dá justamente à proporção que o caráter defensivo da masculinidade pode aparecer, e seu potencial de mudança reside na capacidade de deslocar o discurso hegemônico masculino da defesa e da impermeabilidade para a abertura e a permeabilidade". Para tanto, os autores consideram de fundamental importância que a abordagem feminista e de gênero no trabalho com os grupos reflexivos enquanto referencial teórico e prático das intervenções com esses sujeitos.

Neste sentido, um profissional do Instituto ALBAM ressaltou a importância e o caráter dos grupos enquanto política pública:

\footnotetext{
(...) a gente tem na história da discussão de gêneros sempre de uma linha que defende que o trabalho tem que ser somente focado na mulher e o [Instituto] ALBAM conseguiu inovar ao perceber que pode sensibilizar por outra perspectiva, que é a discussão da masculinidade e, também, da necessidade que é você trabalhar o homem enquanto sujeito que também recebe toda uma carga de cultura machista e de violência; e se você não trabalha essa perspectiva da masculinidade você não consegue desconstruir a violência e gerar uma relação de igualdade. Então, a perspectiva da masculinidade de trabalhar com homem a gente percebe que é fundamental no trabalho de desconstrução de violência de gênero. É por isso que $o$ trabalho está hoje dentro de uma linha metodológica possível a partir da Lei 'Maria da Penha', que eu acho que é um grande avanço do ponto de vista da legislação brasileira. Antigamente, a gente tinha experiência, quer dizer, os grupos vêm desde a década de 70, mas isso não era possível do ponto de vista de uma política pública porque não havia o recorte legal - inclusive do ponto de vista judicial de aplicação de medida garantida por lei. Então, hoje, com a Lei 'Maria da Penha' para os grupos estão previstos... uma previsão legal é que é possível você desenvolver um trabalho
} 
desses através de uma política pública, que é o que o [Instituto] ALBAM faz hoje e se constituiu um grande diferencial no Brasil justamente porque é política pública. É muito importante ser frisado que você está dentro de um Terceiro Setor, mas isso é uma política pública e ela tem que ser universal, tem que ser sistêmica, ela tem que ser colocada à disposição por todas as relações que passam por violência doméstica então, não é a experiência pontual de pessoas que são escolhidas para estarem aqui. (...) De tudo que eu já percebi na minha trajetória de ativista no campo de Segurança Pública pra mim é o trabalho que mais dá resultado do ponto de vista de responsabilização, e aí eu coloco tudo: prisão, prestação pecuniária, prestação de serviço à comunidade e grupos - que é, normalmente, os tipos de penas ou medidas que são aplicadas, que a lei possibilita a aplicação. Então, os grupos eles, justamente, por trabalhar com a questão do conflito, do fato, que gerou a violência, a gente trabalha com foco na responsabilização, então, é o que eu mais percebo essa capacidade de responsabilização - seja ela de mulheres ou homens, né? Porque a gente trabalha sempre o contexto da violência relacional, apesar de que é óbvio que existem casos que é evidente que houve uma violência contra a mulher e que a mulher está no contexto mesmo de vítima; mas, de qualquer forma, a gente trabalha no contexto da violência relacional até pra que essa mulher se fortaleça na possibilidade de romper, ou não, essa relação, mas de qualquer forma impondo esse respeito aos seus direitos e de sua dignidade enquanto pessoa ${ }^{18}$.

Para um dos participantes do segundo grupo reflexivo que acompanhei, o qual também é monitorado de LMP, o fato de estar em situação de cumprimento das medidas judiciais o retirou da vida em sociedade, à qual ele pretende retornar logo depois de cumprir a medida de monitoração. Sua opinião ao longo de nossa conversa me pareceu, de certo modo, otimista no sentido de mudanças de comportamento, apesar de se sentir injustiçado pelo acontecido. Reproduzo um trecho da conversa a seguir.

W: Mas depois que você tirar a tornozeleira, você acha que a sua vida vai mudar muito?

Monitorado 3: Seguir minha vida, voltar para a sociedade de novo, quero seguir o meu caminho de novo.

W: Quando você fala (Fulano) 'voltar para a sociedade de novo', você está falando como se você não estivesse nela...

Monitorado 3: Eu não tenho liberdade nenhuma, eu não tenho liberdade no jogo, não tenho liberdade num restaurante, entendeu? Se eu for num lugar que a pessoa vai te revistar você fica constrangido com aquilo ali [a tornozeleira], o cara bate a mão: 'o que é isso aí?' Você vai mostrar e tal e infelizmente... Peraí. Você não tem direito de namorar. Se você está com uma menina, uma mulher, um exemplo, se vê isso aqui [a tornozeleira] o que ela vai pensar? Como é que você vive desse jeito? 'Peraí, esse cara é um agressor, esse cara é mau'. Sei lá, ‘um bandido’ entendeu? Com isso aqui você não vive não, isso aqui é pior do que você estar preso. Você anda pra tudo quanto é lugar, mas você anda, sabe como é que é... com aquele negócio na cabeça e tal, sei lá, pra mim isso não funciona ${ }^{19}$.

\footnotetext{
${ }^{18}$ Entrevista com profissional do serviço 'Psicossocial' 5, realizada em 22 de novembro de 2013; grifos nossos.

${ }^{19}$ Entrevista com Monitorado 3. Realizada em 15 de junho de 2013. Participante do grupo reflexivo n. ${ }^{\circ} 2$; grifos nossos.
} 
Resta analisar, contudo, se e em que medida essas intervenções em grupos reflexivos de gênero são capazes (ou não) de operar mudanças nas masculinidades que atendam também aos anseios e objetivos desses indivíduos, trazendo como consequência melhoria de qualidade de vida aos mesmos.

Ainda segundo Lattanzio e Barbosa (2013: 97-98),

\begin{abstract}
Não é incomum que, ao final de sua participação como integrante de um grupo, um homem relate como aquela experiência foi importante para suas relações familiares e sociais: as possibilidades de resolver os conflitos de formas dialogais, de conseguir se colocar no lugar do(a) outro(a) e buscar enxergar a partir de sua perspectiva, de verdadeiramente escutar o(a) outro(a), de conseguir identificar e expressar sentimentos em vez de reagir impulsivamente a eles, de ter mais liberdade para exercer a masculinidade de formas não estereotipadas, de se permitir uma relação de maior afeto e proximidade com os filhos e filhas, enfim, uma série de ganhos que faz que a experiência de passar pelo grupo gere qualidade de vida para esses sujeitos e leveza e permeabilidade nas maneiras de se relacionar com o outro.
\end{abstract}

Ressalto, no entanto, que é necessário ter uma visão crítica sobre as intervenções com homens autores de violências intrafamiliares e domésticas sob a forma de grupos reflexivos. Seria ingenuidade acreditar que este ou qualquer outro tipo de metodologia possa trazer mudanças radicalmente definitivas nesses sujeitos, se não forem trabalhados outros aspectos capazes de refletir nas práticas sociais, culturais e políticas, nas representações (coletivas e individuais), nos sentidos atribuídos aos papéis de gênero, à violência e às masculinidades. Deve-se, também, colocar em suspensão a todo tempo o pano de fundo político dessas intervenções de maneira a relativizar inclusive o papel do interventor nesse contexto. Ou seja, até onde vai o militante e até onde é possível ir o interventor, desprovido das parcialidades e convicções ideológicas às quais pode se apegar.

Dessa forma, pensados no contexto social mais amplo, esses grupos devem ser vistos como reflexo da sociedade na qual estão inseridos, sendo que as mudanças dos participantes que por meio deles se espera deve estar diretamente vinculada não unicamente ao 'novo projeto de homem' a ser construído, mas aos propósitos de vida em coletividade, o que requer, também, a contenção, análise e controle das subjetividades. 


\section{ENQUANTO ELES SE (RE)CONSTROEM, ELAS JÁ SÃO... SOBRE INDIGNAÇÃO MORAL E AS DEMANDAS POR RECONHECIMENTO}

Segundo Lagarde (1990: 62),

(...) la condición de género de las mujeres y los hombres es histórica y su contenido es su ser social y cultural, es el conjunto de relaciones de producción y reproducción en que están inmersas, las formas en que participan en ellas, las instituciones políticas y jurídicas que las contienen y norman, y las concepciones del mundo que las definen y las explican. La situación [genérica] se basa en su existencia concreta según sus condiciones reales de vida: formación social donde nacen y viven, relaciones de producción-reproducción.

Contudo, apesar de as condições dos gêneros serem históricas e baseadas nas condições reais de vida de homens e mulheres, tal como afirmado pela autora, essas podem e devem ser desnaturalizadas de tal modo que nos permitam analisar, nos contextos relacionalmente estruturados a partir de assimetrias de poder (de diversas ordens), como a dimensão política das intervenções com homens autores de violências intrafamiliares e domésticas têm corroborado para converter esses indivíduos em sujeitos passíveis de intervenção, responsabilizando-os pela transformação que deles se espera, até que se adequem ao ideal social e normativo das relações sociais de gênero.

A partir dos dados relativos ao trabalho de campo sobre monitoração eletrônica e intervenções psicossociais com homens autores de violência contra mulheres em Belo Horizonte, pude observar que esses mecanismos de subversão de masculinidades violentas sob novos referenciais universais e individualistas de homem, masculinidade, família etc. têm gerado nesses indivíduos sentimentos de indignação moral e ressentimentos, inclusive desembocando na produção de novas demandas por reparação e reconhecimento (L. CARDOSO DE OLIVEIRA, 1989; 2002; 2008; 2010). A seguir, trago trechos da entrevista com um participante de um dos grupos reflexivos de gênero, também monitorado com tornozeleira eletrônica, que reforça esse argumento. 
Eu tava tentando reatar com ela o casamento de 14 anos que eu tinha, aí eu queria sentar e conversar com ela, mas eu estava muito embriagado e não sabia o que eu estava fazendo - aí fui atrás dela, tentando reatar com ela, mas não tem como eu reatar com ela porque eu tava muito alcoolizado, falando muito alto palavras de baixo calão. (...) 'Você é minha mulher, porra!' E mandando algumas pessoas que estavam ao redor tomar naquele lugar... 'Vai tomar no cu!'. Estava alterado demais, muito alcoolizado, (...) puxando ela, querendo conversar com ela e ela: 'Não (Fulano), vai embora que você não tem condição nenhuma de conversar comigo'. Mas mesmo assim eu queria conversar com ela e nesse dia por azar meu tinha na minha bolsa uma chave de fenda, aí os policiais que viram disseram que eu tinha intenção de matar ela, mas eu não tinha intenção de matar ela, afinal tenho 14 anos de vida com ela. (...) Queria voltar. A gente se encontrou algumas vezes pra transar, pra curtir e, mesmo assim, ela não queria voltar e foi quando aconteceu esse fato que eles entenderam tudo errado e me colocaram na cadeia. (...) a vizinha que morava do lado de cá, me contou que ela estava saindo com outro homem mas eu não sabia se era verdade ou se era mentira, uma fofoca dela. Aí peguei (...), uma marreta de 20 quilos, peguei um bocado de coisas, eu não lembro muito, sei que foi um bocado de coisas e quebrei a casa toda, destruí a casa toda e tudo que tem dentro, as paredes... carro... saí de casa e fui morar na rua. (...) 'Você quer a casa? Você quer tudo? Vou te dar a casa do jeito que você quer'. Aí eu quebrei tudo, quebrei tudo e aí chamaram a Polícia e a Polícia fez a ocorrência (...) Nisso eu falei: 'Quem vai embora hoje vai ser nós dois, não eu sozinho'. Saí de casa e fui morar na rua, fiquei um ano morando na rua em Belo Horizonte, um ano igual louco, um ano batendo cabeça, chorando, usando drogas. (...) Tomei veneno, mas veneno não mata gente ruim não... eu tomei foi muito. (...) Eu queria morrer, já estava de saco cheio e insatisfeito de viver e achava que a minha vida não tinha mais solução (...) [O que fez você mudar?] Esse grupo daqui, eu passei pelo grupo; e tem outro grupo que eu participo da igreja - Igreja Universal - estou participando lá também, tem (...) quem orienta a gente e isso está me ajudando, eles me chamam lá pra conversar, pra saber como está o andamento, como está minha cabeça; mas no começo não, no começo eu nem vinha aqui, achava que não tinha necessidade de passar aqui não e como eu já estava morando na rua, passando fome praticamente, tinha que ficar pedindo aos outros, humilhando por aí afora... E esse negócio não deixa arrumar emprego, pra arrumar emprego em Belo Horizonte foi muito difícil. (...) [Você sofreu algum tipo de discriminação ou preconceito por estar usando tornozeleira?] Sim, várias vezes. (...) Eu já tive no ponto de ônibus de bermuda e as pessoas se afastaram de mim; já tive pra entrar no shopping e ser barrado dentro do shopping - eu estou até com uma ação na Justiça por causa disso, sabe? Até na minha casa as pessoas não conversam comigo mais, onde eu estou morando, têm medo por causa disso e acham que eu sou um traficante bravo, sei lá, (...) nunca pensa por outro lado, da medida protetiva por causa da 'Maria da Penha', já tentei explicar isso, mas não tem chance porque ninguém acredita. Deixa eu sair na rua pra você ver como as pessoas olham, se tiver de bolsa seguram a bolsa e sai até de perto - isso já aconteceu isso comigo; o sinal está fechado e as pessoas ligam o carro com medo da tornozeleira. 'É bandido, não sei que...', e saem andando com o carro; até os amigos se afastou de mim, amigos, amigas, ninguém fica perto não. (...). Aí eu cheguei aqui [ao grupo reflexivo], no primeiro dia que eu cheguei aqui não gostei não e depois foi trabalhando mais a minha mente, hoje me ajudou, em vez de estar me prejudicando está me ajudando; mexeu muito com a minha cabeça e, graças a Deus, senão não estava não... se não tivesse esse grupo eu tava meio louco, nem vivo eu tava eu tinha tirado minha própria vida há muito tempo ${ }^{20}$.

\section{Conforme pontuou L. Cardoso de Oliveira (2012), certas disputas ou conflitos}

\footnotetext{
${ }^{20}$ Entrevista com monitorado 15, realizada em 25 de novembro de 2013. Participante do grupo reflexivo n. ${ }^{\circ}$ 9; grifos nossos.
} 
judicializados não encontram solução apropriada sem que se discuta a dimensão do reconhecimento, sendo que 'a satisfação da demanda por reconhecimento requer que os atorescidadãos percebam neste um interlocutor capaz de levar a sério suas alegações’. Segundo L. Cardoso de Oliveira (2003: 5), as demandas judiciais possuem três dimensões:

(1) a dimensão dos direitos vigentes na sociedade ou comunidade em questão, por meio da qual é feita uma avaliação da correção normativa do comportamento das partes no processo em tela; (2) a dimensão dos interesses, por meio da qual o judiciário faz uma avaliação dos danos materiais provocados pelo desrespeito a direitos e atribui um valor monetário como indenização à parte prejudicada, ou estabelece uma pena como forma de reparação; e, (3) a dimensão do reconhecimento, por meio da qual os litigantes querem ver seus direitos de serem tratados com respeito e consideração sancionados pelo Estado, garantindo assim o resgate da integração moral de suas identidades.

Sendo assim, 'o modo judicial de avaliar disputas tende a colocar limites às opções das partes para o equacionamento das causas'. O fato de os 'batedores de mulheres' não serem devidamente ouvidos pelas autoridades também em seu potencial elucidativo dos casos faz com que essa demanda lhes seja arbitrária e autoritariamente negada. Além disso, o processo de construção dos 'Maria da Penha' é justificado a partir não somente na versão individual de uma das partes envolvidas (a da 'vítima'), como também de princípios universalistas e englobantes do direito que, no final, acabam não refletindo em equanimidade, mas em desconsideração a esses sujeitos.

Demandas por reconhecimento também emergem a partir das dinâmicas realizadas nos grupos reflexivos com homens autores de violência. Trago ilustrativamente, a seguir, a imagem um cartaz confeccionado a partir do trabalho com recortes e colagens pelos participantes de um grupo. A proposta era a de que os mesmos refletissem sobre 'Ser Homem', sendo que, para cada figura ou recorte deveria ser atribuída uma legenda explicativa. 


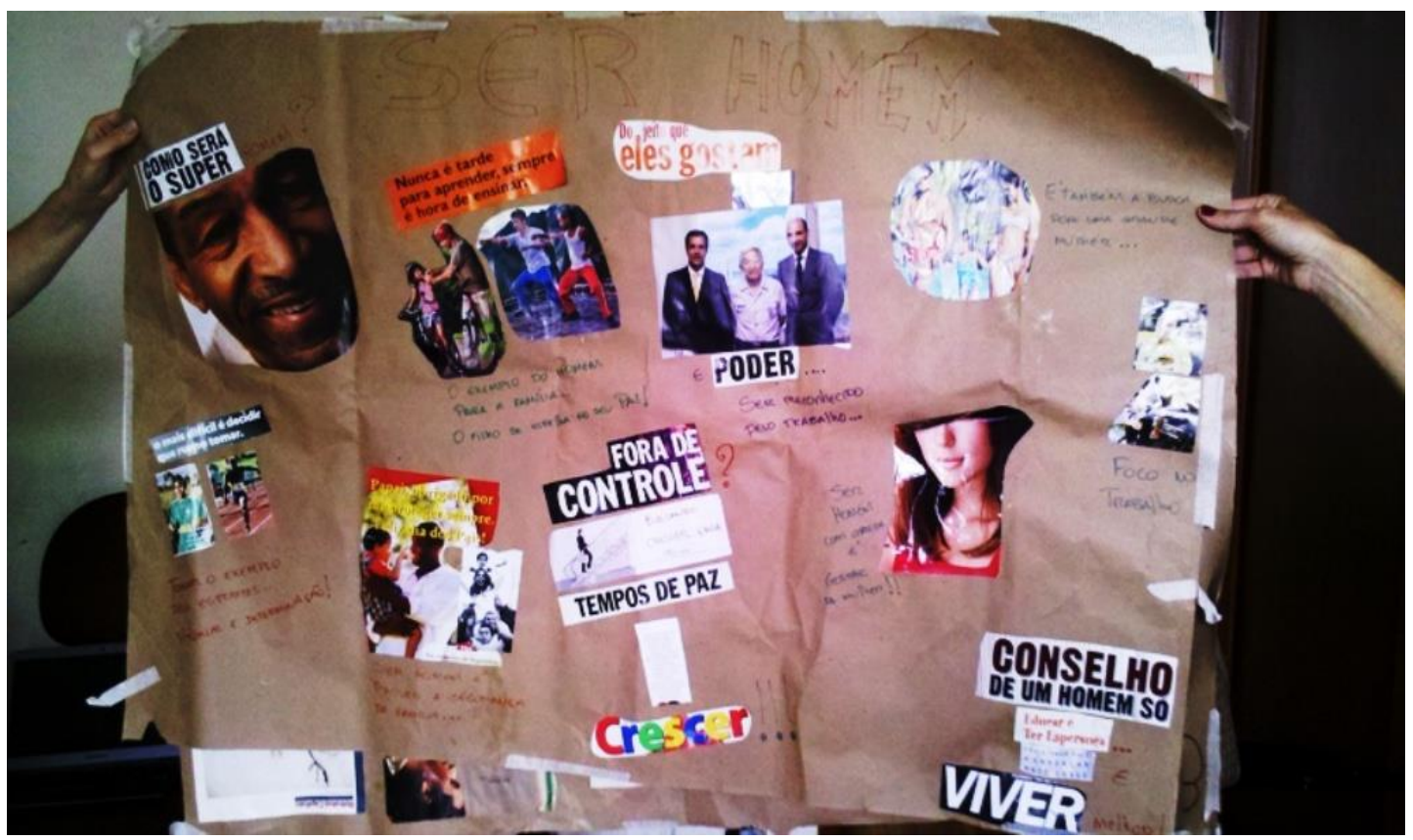

Foto 1 - 'Ser Homem'. Material de Grupos Reflexivos. Instituto ALBAM - Fonte: Arquivo Pessoal.

Repare o/a leitor/a que, dentre as frases citadas pelos participantes, nenhuma delas remete à questão da violência, mas buscam desconstruir sua relação com a masculinidade em busca de reconhecimento pessoal, profissional, da família, da companheira, dos filhos etc. Destaco algumas: "o exemplo de homem para a família"; "o filho se espelha no seu pai"; "poder ser reconhecido pelo trabalho"; “nunca é tarde para aprender, sempre é hora de ensinar”; "é também a busca por uma grande mulher"; “como será o super homem?”. A resposta a esta última frase, talvez, seja a grande incógnita da transformação dos 'Maria da Penha' que, ao final desse processo, têm um 'pacote' de novas atribuições não necessariamente construídas por eles, mas às quais devem se ater para ser 'novos homens', a partir de um 'projeto de masculinidade' talvez não muito claro dentro dos objetivos das políticas públicas em curso naquela localidade. Assim, restam algumas perguntas, dentre elas: será que querem esses sujeitos, de fato, se adequar a esse novo modelo ou 'projeto de masculinidade'? A simples adequação a partir de uma subversão (desejada, auto desejada, colocada ou imposta) poderá por si só apontar não apenas para certo apaziguamento das relações afetivas protagonizadas pelos mesmos e suas companheiras, como também para a satisfação das demandas individuais de ambos no contexto da relação? 


\section{NOTAS (IN)CONCLUSIVAS...}

Analisar a percepção de atores institucionais e, principalmente, dos próprios indivíduos diretamente envolvidos no cumprimento de medidas judiciais sob o recorte de gênero, bem como o processo de construção de uma 'responsabilização' atribuída a esses sujeitos por meio da dinâmica das intervenções grupais e reflexivas como forma de enfrentamento à violência doméstica, mostrou-se tarefa árdua e, ao mesmo tempo, desafiadora.

Dada à riqueza do material de campo, optei por analisá-lo aos poucos, na medida em que ele era apresentado ao longo do texto. Obviamente, não em sua completude, o que demandaria muitas páginas a mais de escrita e reflexão. Todavia, o/a leitor/a chega ao final da leitura com alguma bagagem em termos de conclusões parciais levantadas ao longo do texto, às quais não serão descoladas dos diversos contextos aos quais iluminaram a discussão.

Conforme constatado em outra ocasião ${ }^{21}$, podemos afirmar que políticas públicas com perspectiva de gênero implementadas naquela localidade têm sido reforçadas ao longo dos anos, almejando-se com isto romper os ciclos de violências entre homens e mulheres, sob as chancelas de legislações específicas, recorrendo, inclusive, a novas tecnologias e dispositivos de controle dos/sobre os corpos.

Ainda que não haja consenso entre os atores institucionais, percebemos que a aplicação da monitoração de homens autores de violências contra mulheres por meio de tornozeleiras eletrônicas na RMBH tem buscado garantir o cumprimento de outras medidas protetivas e, quando aplicada conjugadamente com a obrigatoriedade desses homens em frequentarem grupos reflexivos de gênero, tem proporcionado a alguns deles refletirem sobre suas ações individuais, mas também despertado sentimentos de indignação e revolta em outros.

Não nos esqueçamos, no entanto, de que os espaços das intervenções com esses sujeitos são espaços políticos, cuja conformação só se fez possível a partir de demandas socialmente construídas, sendo que a reflexão neles propiciada deve ser a reflexão da própria sociedade sobre os sujeitos que dela/nela se constituem. Apesar de todas as críticas, as intervenções com

\footnotetext{
${ }^{21}$ CAIXETA MACIEL, Welliton. Da judicialização das relações intrafamiliares à ressignificação do cárcere: sobre violências, tornozeleiras e descontroles em Belo Horizonte/MG. Revista O público e o privado - $\mathrm{N}^{\circ} 26-$ Julho/Dezembro, 2015.
} 
homens agressores de mulheres têm se revelado como alternativa à possibilidade de mudanças nos esquemas mentais, atitudinais e culturais dos sujeitos sociais diretamente envolvidos, sobretudo, dos homens em relação às mulheres, com a resolução de conflitos de formas dialogais, maior liberdade para exercício da masculinidade de formas menos estereotípicas, capazes de repercutir positivamente nas relações intrafamiliares e nas relações sociais. Ressaltese, todavia, que, depois desse processo interventivo, não existem garantias de que os homens não se identificarão mais nem se deixarão conduzir segundo valores tradicionais de masculinidade. Ou seja, a questão das masculinidades violentas é demandante de mudanças culturais mais significativas.

Não sabemos nem temos como afirmar, portanto, se esse tipo de violência tem se reduzido, nem qual o efeito e o impacto das medidas protetivas e punitivas na percepção das pessoas, se e de que forma as partes têm superado seus conflitos, ou sobre o comprometimento com a reparação de danos pelos responsabilizados por essas violências, se a legislação tem contribuído para a construção de uma cultura de paz etc.

Diante deste contexto, sugere-se que sejam estimulados os espaços destinados à construção de soluções participativas, na esteira do que afirmou Mourão (2013: 134), com relação aos processos de escuta, de maneira a viabilizar fluxos narrativos e o estabelecimento de pontes no plano da comunicação entre esses sujeitos voluntariamente. Assim como a autora, "não acredito que processos nos quais os envolvidos não tenham espaço para expressar suas próprias definições do problema, suas necessidades e demandas, possam gerar qualquer tipo de responsabilização".

\section{REFERÊNCIAS BIBLIOGRÁFICAS}

ACOSTA, Fernando et. al. Conversas homem a homem: grupo reflexivo de gênero metodologia. Rio de Janeiro: Instituto Noos, 2004.

BRASIL. Presidência da República. Lei n. 11.340, de 7 de agosto de 2006.

BRASIL. Presidência da República. Lei no 9.099, de 26 de setembro de 1995.

CAIXETA MACIEL, Welliton. Os "Maria da Penha": uma etnografia de mecanismos de vigilância e subversão de masculinidades violentas em Belo Horizonte. (Dissertação de 
Mestrado). Programa de Pós-Graduação em Antropologia Social da Universidade de Brasília, 2014.

. Da judicialização das relações intrafamiliares à ressignificação do cárcere: sobre violências, tornozeleiras e descontroles em Belo Horizonte/MG. Revista O público e o privado - No 26 - Julho/Dezembro, 2015.

CARDOSO DE OLIVEIRA, Luís Roberto. Fairness and communication in small claims courts. (PhD. Dissertation, Harvard University), Ann Arbor: University Microfilms Internal, 1989.

Direito Legal e Insulto Moral: dilemas da cidadania no Brasil, Quebec e EUA. Rio de Janeiro: Relume Dumará, 2002.

Honra, dignidade e reciprocidade. Série Antropológica, 344, pp. 2-16. Brasília: DAN/UnB. Também publicado em MARTINS, P.H. \& NUNES, B. F. (Orgs.). 2004. A nova ordem social: perspectivas da solidariedade contemporânea. Brasília: Ed. Paralelo 15, 2003.

. Existe violência sem agressão moral? Revista Brasileira de Ciências Sociais, v. 23, nº 67, São Paulo, 2008.

. A dimensão simbólica dos direitos e a análise de conflitos. In: Revista de Antropologia volume 53(2) 451-473. USP: São Paulo, 2010.

. Moral e Ética. In: LIMA, Antonio Carlos de Souza (Org.). Antropologia \& Direito - temas antropológicos para estudos jurídicos. Rio de Janeiro/Brasília: Contra Capa/ABA, 2012.

LAGARDE, Marcela. Cautiverios de las mujeres. México: Ed. UNAM, 1990.

LATTANZIO, Felippe Figueiredo; BARBOSA, Rebeca Rohlfs. Grupos de gênero nas intervenções com as violências masculinas: paradoxos da identidade, responsabilização e vias de abertura. In: Atendimento a homens autores de violência doméstica: desafios à política pública. Rio de Janeiro: ISER, 2013.

LEITE, Fabiana; LOPES, Paulo Victor Leite. Serviços de educação e responsabilização para homens autores de violência contra mulheres: as possibilidades de intervenção em uma perspectiva institucional de gênero. In: Atendimento a homens autores de violência doméstica: desafios à política pública. Rio de Janeiro: ISER, 2013.

LIMA, Daniel Costa; BÜCHELE, Fátima. Revisão crítica sobre o atendimento a homens autores de violência doméstica e familiar contra as mulheres. Physis Revista de Saúde Coletiva, Rio de Janeiro, 21 [ 2 ]: 721-743, 2011.

MOURÃO, Barbara Musumeci. Entrevista com Barbara Musumeci Mourão, por Carla de Castro Gomes e Paulo Victor Leite Lopes. In: Atendimento a homens autores de violência doméstica: desafios à política pública. Rio de Janeiro: ISER, 2013. 
NOTHAFT, Raíssa Jeanine; BEIRAS, Adriano. O que sabemos sobre intervenções com autores de violência doméstica e familiar?. Revista Estudos Feministas, Florianópolis, v. 27, n. 3, e56070, 2019.

OLIVEIRA, Kátia Lenz Cesar de; GOMES, Romeu. Homens e violência conjugal: uma análise de estudos brasileiros. Revista Ciência \& Saúde Coletiva, 16(5): 2401-2413, 2011.

PORTAL VIOLÊNCIA CONTRA A MULHER. Centro pioneiro promove reeducação de autores de violência contra mulheres, 2009. Disponível em: www.violenciamulher.org.br .

SAFFIOTI, Heleieth I. B. Gênero, patriarcado, violência. Brasil Urgente. São Paulo: Editora Fundação Perseu Abramo, 2004. 